and lead to paralysis. It is relatively rare, affecting 4-7 in 100,000 people. But there is no cure, and no good understanding of its cause.

The ice-bucket challenge emerged in the United States in July and went viral around the globe, peaking in August. During that month, the ALS Association in Washington DC received more than US $\$ 100$ million in donations, compared with $\$ 2.8$ million collected during August 2013. Already, the association has distributed some $\$ 20$ million of that for research. ALS societies in Germany and the Netherlands hauled in more than $\$ 1$ million each. Australia managed more than $\$ 2$ million and Japan more than a quarter of a million. The UK Motor Neuron Disease (MND) Association in Northampton attracted 910,000 donations in just three August weeks, compared with its average monthly score of 13,000. Research has never benefited from a social-media phenomenon to this extent before.

The success of the activity is an endorsement of medical research by the general public. The associations that benefited have been careful to explain that the money will be distributed through expert review. This means that only the best research will be funded. Yet during all the excitement, what mention was made of the fact that research leading to effective treatments will eventually, one way or another, require the use of animals?

The research collaborations chosen on 2 October in the ALS Association's first round of funding are mostly based on human genomic and stem-cell approaches, which tactfully avoids the animal issue. By contrast, beneficiaries of the MND Association's windfall include both clinical research and research that uses animal models. ALS is a disease that can be caused by different factors in different people. Because its aetiology is so poorly understood, the animal models generated so far — in, for example, flies, mice and monkeys — are not totally reliable. Much will be gained from the human-genetic approaches now under way. They could help to develop better animal models.

Would members of the public have participated so joyously in the activity if they had known that research on animals might benefit from their donations? Had that sensitive question been raised, the mood might have been different and its consequences for medical research damaged. But glossing over the reality of such research is not a good strategy for avoiding crises; instead, life scientists and their organizations should take every opportunity to say when animals have been used in research, and to explain why. Societal discussions about responsible animal research need to take place outside periods of crisis.

It is encouraging to see the tide slowly turning towards such openness - witness the MND Association's upfront funding of the full spectrum of necessary research. And outside the ice-bucket excitement, last week
"There are many ways to support medical research." saw another major advance. On 13 October, the US Society for Neuroscience and the Federation of European Neuroscience Societies combined their might to publish, for the first time, a public statement in support of a neuroscientist under attack: Nikos Logothetis, a director at the Max Planck Institute for Biological Cybernetics in Tübingen, Germany, who works with monkeys. His lab had been infiltrated by an animal activist who filmed the primates there, and the videos were used as propaganda by organizations opposed to any research on animals. (An independent investigation at the institute declared that there were no systematic problems with animal care there.)

This sort of vocal support for research is important. Logothetis's work on the brain is fundamental, but applied research on degenerative diseases, including ALS, will be aided by a better understanding of the complex organ in which the diseases originate.

There are many ways to support medical research. Engaging people's enthusiasm with actions such as the ice-bucket challenge is an important one. Public support by scientific organizations for the responsible actions of their members is another. The challenge is great, the need even greater.

\section{Toxic influence}

\section{Europe must act to stop livestock drugs from wiping out its vulture populations.}

A dead vulture in Spain could herald a crisis for raptor populations, because a drug that has killed hundreds of thousands of birds and driven some species to the brink of extinction in Asia now threatens to do the same in Europe. The European Medicines Agency (EMA) must clamp down on the drug.

The Spanish bird died two years ago. Now, the probable cause has been identified as a drug given to livestock (I. Zorrilla et al. Conserv. Biol. http://doi.org/wf5; 2014). Events in Asia show how serious the consequences could be. In the 1990s, vultures on the Indian subcontinent started dying in huge numbers. Some populations lost more than $95 \%$ of their animals. The consequences were catastrophic. As the skies cleared, dead livestock were left to rot in fields.

Research finally pinned the blame on the anti-inflammatory drug diclofenac, which had become widely used in cattle for problems ranging from pneumonia to mastitis. Although harmless to bovines, it is highly toxic to vultures that feed on the carcasses (J. L. Oaks et al. Nature 427, 630-633; 2004).

As a result, India, Pakistan and Nepal placed heavy restrictions on the use of the drug in livestock. And although campaigners say that large vials officially designated for human use are often repurposed by veterinarians, the threat to the vultures of Asia has decreased. Numbers have not yet recovered, and in some cases are still declining, but the birds at least now stand a chance.

Europe is heading in the opposite direction. Despite warnings from scientists, Spain - home to the vast majority of Europe's vultures - last year licensed diclofenac for livestock use. The EMA is considering the risks posed by the drug, and is scheduled to reach a decision by the end of November.

The discovery that the 2012 vulture was probably felled by a related drug, called flunixin (see Nature http://doi.org/wfx; 2014), is worrying for two reasons. First, it shows that diclofenac is not the only product in the class known as non-steroidal anti-inflammatory drugs (NSAIDs) that has the potential to kill vultures and other birds of prey. Second, it shows that carcasses containing significant quantities of these drugs are reaching the wild-animal food chain in Europe - in this case, probably through the Spanish tradition of wild-animal feeding stations known as muladares.

Two things should now happen. The EMA must move to heavily restrict - if not ban - the use of diclofenac in livestock. An alternative drug that does not harm vultures - meloxicam — is already available, and vets should use this in preference. And, as urged by the researchers who reported the flunixin-killed vulture, regulators should look at the effects of all NSAIDs used in livestock on vultures. Although diclofenac could well be the most deadly, we must know what other drugs also pose a threat to birds that feast on carrion, and how they might be managed.

In the longer term, regulators in Spain and the rest of the European Union need to ask how a drug with such evidence of environmental damage was allowed to come onto the market.

Spain is an important stronghold for vultures, and this alone would be reason enough to look seriously at restricting the use of diclofenac. $\rightarrow$ NATURE.COM To comment online, click on Editorials at: go.nature.com/xhunqv But the European Union needs to set an example for the rest of the world. If it allows diclofenac use to continue, countries such as India could well decide to ease their restrictions, and African nations may rethink their plans to ban it. 